\title{
BALANCED SCORECARD PERSPECTIVE ON CHANGE AND PERFORMANCE: A STUDY OF SELECTED INDIAN COMPANIES
}

\author{
*Ayesha FAROOQ \\ *Zareen HUSSAIN \\ *Aligarh Muslim University, India
}

\begin{abstract}
Balanced scorecard helps organizations to streamline vision and strategy with business activities and measures actual organizational performance against preset goals. In addition this instrument is used to assess financial processes, customer relations, internal business processes and learning and growth characters of an organization. The purpose of this study is to recognize the role balanced scorecard and change management play in better performance of organizations. The work also gains an insight into the effects of balanced scorecard and change on organizational performance. For the purpose, a questionnaire is developed and responses were collected from organizations which were segregated on the basis of public and private sector and also manufacturing and service industry. Statistical tools such as t-test and Correlation were applied to achieve the objectives.
\end{abstract}

Keywords: Balanced Scorecard, Change Management, Organizational Performance.

\section{INTRODUCTION}

Neely et al. (2002) defines performance measurement and performance measurement system. Performance measurement is the process of quantifying the efficiency and effectiveness of past action. A performance measurement system enables informed decisions to be made and actions to be taken because it quantifies the efficiency and effectiveness of past actions through the acquisition, collation, sorting, analysis and interpretation of appropriate data. Through the years, the Balanced Scorecard has evolved, from the performance measurement tool originally introduced by Kaplan and Norton (1992), to a tool for implementing strategies (Kaplan and Norton, 1996) and a framework for determining the alignment of organization's human, information and organization capital with its strategy (Kaplan and Norton, 2004).

Organizational change refers to the adoption of an idea, procedure, process, or behavior that is new to an organization (Pierce and Delbecq, 1977). Recent developments have reinforced the view of Stickland (1998), who believes that we are moving from a world in which we determined our destination to one on which we must learn to navigate a path between myriad and future possibilities. Morgan (1989) suggested that the increasing turbulence would necessitate the adoption of a more proactive and entrepreneurial policy within the organization. The most well- developed view is that change generally is motivated by events in an organization's environment- some problem or surprise such as shortfall in expected performance, unexpected moves by competitors, shifts in technology, or new customer demand triggers a change (March and Simon, 1958; Cyert and March, 1963; Hedberg, 1981; Levitt and March, 1988).

Despite the development of dozens of frameworks and techniques for measuring intangible assets such as intellectual capital and knowledge, a question arises whether the internal measurement of intangible assets for management purposes is associated with higher performance. Researches also highlight the role of balanced scorecard in the effective management of change. Study by McDevitt, Giapponi and Solomon, 2008; Beard, 2009 highlighted the successful implementation of balanced scorecard to revitalize the faculty and academic divisions. Narrett (2008) informs how Balanced Scorecard Strategic Management System helped PSE\&G, America's largest combined electric and natural gas company, set new levels of excellence in reliability, safety, innovation, and overall performance.

This paper aims at discovering a relation between balanced scorecard and change management. It also intends to illustrate the function of balanced scorecard in the effective management of change and resulting effective performance. To achieve this objective, literature related to balanced scorecard and 
change is reviewed. Studies presenting the successful employment of balanced scorecard for valuable change management are also appraised. In the light of literature review, hypotheses were formulated followed by research design and analysis. This article also examines the implications for theory and managerial practice.

\section{DEFINING BALANCED SCORECARD (BSC)}

The balanced scorecard, first proposed in the January- February 1992 issue of HBR ("The Balanced Scorecard- Measures that Drive Performance"), provides executives with a comprehensive framework that translates a company's strategic objectives into a coherent set of performance measures (Kaplan and Norton, 1993). During a year-long research venture with 12 companies at the leading edge of performance measurement, Kaplan and Norton (1992) devised a "balanced scorecard"- a set of measures that provide top managers a fast but comprehensive view of the business. Kaplan and Norton (1992) understood that as the business landscape changed from agricultural to industrial to informational; performance measures must adapt as well. The information age is characterized by the conversion of intangible (employee skills, customer satisfaction, and information technology) rather than intangible assets (property, plant, and inventory) into competitive advantage (Kaplan and Norton, 2000). BSC includes financial measures that tell the effects of actions already taken. And it complements the financial measures with operational measures on customer satisfaction, internal processes, and the organization's innovation and enhancement activities- operational measures that are the drivers of future financial performance (Kaplan and Norton, 1992).

The four perspectives of BSC are Financial Perspective, Customer Perspective, Internal Business Process Perspective and Learning and Growth Perspective.

Financial Perspective: It represents the long- term goal of the organizations- to provide superior returns based on the capital invested in the unit (Kaplan and Norton, 1996). Financial Measures, has been the traditional method of analyzing organizational success and involves such elements as profitability, sales growth, and revenue per sales visit. Although the BSC stresses the need to incorporate additional measures to determine success, the need for Financial Measures is still an extremely strong element to determine success (Niven, 2002)

Customer Perspective: Choosing measures for the Customer Perspective of the BSC depends on the type of customers desired and the value that the organization provides to them (Niven, 2002). The purpose of the Customer Perspective is to focus on the target customers. This will allow organizations to create strategies consistent with the type of customers they want to attract.

The Internal Process Perspective: It entails the procedures that an organization must develop and master to be successful. Many organizations will concentrate on such elements as order processing, delivery, manufacturing, and product development as examples (Niven, 2002). The focal point of this perspective is related to the Customer Perspective because to keep customers satisfied, an organization will need to focus on the components of the organization important to them. If target customers are dissatisfied when delivery is late, an organization must concentrate on the internal process of developing a more efficient delivery system or refining the system currently used. To accomplish this, managers are undertaking a rigorous internal analysis not only assessing the internal processes of the organization, but reviewing innovation since global competition has decreased the amount of time organizations can bring their products to market to be successful (Bose \& Thomas, 2007; Levy, 1998).

Learning and Growth Perspective: According to Kaplan and Norton (1996b), this perspective is the backbone to a successful scorecard because it involves employee skills and information systems. Learning and Growth can include such issues as employee satisfaction, alignment of employee skills with jobs, number of employee suggestions implemented, and hours of employee training. Depending on the actual employee skills and desired employee skills, some organizations change job descriptions, relocate employees to other departments, and/or implement incentive programs designed to motivate employees to provide suggestions, receive education or training, and/or gain tenure through continued employment (Niven, 2002).

\section{DEFINING CHANGE}

Many organizational events are commonly classified as change, including restructuring, downsizing, mergers and acquisitions, strategic change, and cultural change. Van De Ven and Poole (1995) defined change as "an empirical observation of difference in form, quality, or state over time in an organizational entity" ( p. 512). Struckman and Yammarino (2003) defined organizational change as "a 
managed system, process, and/or behavioral response over time to a trigger event" (p. 10). This definition focuses on change as a process or action. The notion of "resistance to change" is often attributed to Kurt Lewin (1951).

Lewin evolved his concept "based on the 'person' as a complex energy field in which all behavior could be conceived of as a change in some state of a field" (Marrow, 1957, p. 30). The status quo represented an equilibrium between the barriers to change and the forces favoring change. He believed that some difference in these forces - a weakening of the barriers or a strengthening of the driving forces - was required to produce the unfreezing that began a change. He held that it was more effective to weaken the barriers than to strengthen the drivers (Dent \& Goldberg, 1999). Scholars disagree on the source of resistance in Lewin's analysis. For George and Jones (2001), Lewin emphasized the role of the individual. According to George and Jones (2001, p. 419), "Lewin's (1951) early forcefield analysis clearly put the person at the center of attention, with forces for change battling against individual resistances to change such as habits and routines, and dislike of insecurity and the unknown (Coch \& French, 1948; French \& Bell, 1990)." Other scholars state that Lewin saw work taking place within a system of roles, attitudes, behaviors, norms, and other factors, any and all of which could cause the system to be at disequilibrium. In this sense, resistance to change was a systems phenomenon, not a psychological one (although the psychology of humans in the system certainly is an element of the total system) (Dent \& Goldberg, 1999). Further the kinds of changes change agents can bring are elaborated by Robbins (2001). Up gradation of technology, training employees regarding upcoming plans and targets and encouraging informal channels are few of the modes to bring technological, people and structural changes respectively.

\section{FACTORS INFLUENCING PERFORMANCE}

\section{Balanced Scorecard vis-à-vis manufacturing and service industry}

A wide range of research documenting the application of BSC in healthcare (Wachtel et al., 1999), education (Lawrence and Sharma, 2002), banking (Littler et al., 2000), retailing (Thomas et al., 1999) has been reported. Chan (2009) exemplifies the evolving applications of BSC and strategy map in the healthcare sector in Ontario, Canada. A number of innovative approaches adopted by healthcare organizations and health systems in their implementation of Kaplan and Norton's strategy map and balanced scorecard are described. In 1995, Peel Memorial Hospital in Brampton, Ontario, BSC provided with a "framework for performance management and evaluation; the ability to translate the organization's strategic objectives into coherent performance measures; the alignment of seemingly disparate elements with organizational objectives and a focus on accountability at all levels.

Hypothesis 1: There is significant difference on mean scores of Balanced Scorecard vis-à-vis manufacturing and service industry.

\section{Change vis-à-vis manufacturing and service industry}

More than a decade ago, at the end of the dot-com boom, the IBM business model was facing challenging times with the continuing decline of its mainframe business and the commoditization of the firm's personal computer market. Bramante et al. (2010) highlights the efforts IBM made to resurrect itself provide meaningful lessons for other multinational corporations looking to pursue higher margins, globalize their operations, and change and reduce their cost structures. Randall and Coakley (2006) proposes Heifetz's adaptive leadership model as the primary process for initiating change in today's more business-oriented academic environment in which colleges and universities are required to compete to attract students and are facing greater scrutiny and accountability from outside constituencies. Another study by Issel and Narasimha (2007) identify ways for organizationally complex, community-based health improvement initiatives to avoid "failures" with regard to client outcomes.

Hypothesis 2: There is significant difference on mean scores of Change vis-à-vis manufacturing and service industry.

\section{Balanced Scorecard vis-à-vis private and public sector}

Peteraf and Reed (2007) investigate the effects of regulatory constraints and their relaxation on managerial discretion and internal fit in the context of the U.S. airline industry. The ability to achieve fit 
under changing conditions may express a dynamic managerial capability necessary for adaptive organizational change. Moreover, broad- based use of efficiency programs such as six sigma has expanded the use of balanced scorecard in major US businesses like GE, 3M and American Express (Niven, 2003).

Hypothesis 3: There is significant difference on mean scores of Balanced Scorecard vis-à-vis private and public sector.

\section{Change Management vis-à-vis private and public sector}

Clemmer (2007) says change and improvement processes adjust to the shifting environment and what's being learned about what works and what doesn't. Federal, state and local governments in the United States invests hundreds of millions of dollars in university leadership courses, executive development programs and off- site retreats for mid- level and senior managers to bring effective change in the existing practices (Kramer, 2007). Bloomfield and Hayes (2009) consider the UK Government's major modernization program for local government and its aim to use technology to bring about a radical transformation in the delivery of public services. In the USA, initial research investigating the power of specific turnarounds strategies such as school improvement planning (Mintrop and MacLellan, 2002); the provision of expert assistance (Duke, 2007; McColskey and Monrad (2004); Mintrop and Trujillo, 2005); adoption of comprehensive reform models (Brady, 2003; Wang and Manning, 2000); and reconstitution and related takeover strategies, including privatization (Borman et al., 2000; Cibulka, 2003; Kowal and Hassel, 2005; Phenix et al., 2005) is underway. At HSBC Argentina, few weeks' program and new language started to emerge surrounding new behaviors and new ways of working, all of which could be experienced through everyday interactions. According to Pollitt (2010), HSBC Argentina engaged the entire organization in changing its culture through the application of tens of thousands of specific and individual actions.

Hypothesis 4: There is significant difference on mean scores of Change vis-à-vis private and public sector.

\section{Balanced Scorecard and Organizational Performance}

Kaplan and Norton define BSC as "a framework that helps organizations translate strategy into operational objectives that drive both behavior and performance (Kaplan and Norton, 2002). Ittner (2008) provides an overview of the statistical evidence on the performance consequences of intangible asset measurement. There are some evidences that non- financial performance measures are positively associated with performance (Abernethy an Lillis, 1995; Ittner and Larcker, 1995; 1997; Chenhall, 1997; Perera, Harrison and Pole, 1997; Ittner et al., 2003; Kaynak, 2003; Said et al., 2003; Davis and Albright, 2004). It has been suggested that companies adopting performance measurement system would improve their corporate performance and profitability by identifying the causal relationships between actions and performance (Buhaovac and Slapničar (2007). Xiong et al. (2008) examines the results of a survey that found that most Chinese firms have used non- financial performance measures to maintain a competitive advantage. Thompson and Mathys (2008) advocate the use of an Aligned Balanced Scorecard as a means to enhance the scorecard approach in order to improve leadership effectiveness as a tool for developing high performance management systems.

Hypothesis 5: There is significant relationship between Balanced Scorecard and Organizational Performance.

\section{Change and Organizational Performance}

Idris and Ali (2008) highlight that many of the organizations competing in the fast-changing business environment are in a constant search for a robust strategy to help survive the new global economic order, making achieving improved performance continuously imperative. Yeo (2007) examines the relationship between change interventions and organizational learning. It seeks to identify the factors that affect organizational learning and its influences on organizational effectiveness.

Hypothesis 6: There is significant relationship between Change and Organizational Performance.

\section{Balanced scorecard and Change}

Several empirical studies find out that non- financial measures such as customer satisfaction are positively related to financial indicators such as stock prices and revenues (Amir and Lev, 1996; Ittner and 
Larcker, 1998; Banker, Potter and Srinivasan, 2000). Comparing financial performances of two sets of banking branches of the same institution before and after one set has implemented a BSC, Davis and Albright (2001) find that the financial performances of the branches that implemented the Balanced Scorecard system improved while the financial performance of the control set of branches did not change. Narrett (2008) enlightens how Balanced Scorecard Strategic Management System helped PSE\&G, America's largest combined electric and natural gas company, set new levels of excellence in reliability, safety, innovation, and overall performance. As a result of using BSC, the company reduced customer complaints by 40 percent, described successful operations, got people throughout the organization focused on activities to produce better outcomes, and transformed PSE\&G's culture into one that emphasize excellence, accountability, and continuous improvement. Beard (2009) present results of successful implementation of BSC at the Kenneth W. Monfort College of Business at Nothern Colorado, a 2004 Malcolm Baldrige National Quality Award recipient, and at the University of Wisconsin- Stout, the first university to receive the award in 2001. An adapted form of the Balanced Scorecard is a component of the Malcolm Baldrige National Quality Award (2003). The program is the vehicle of implementation for Malcolm Baldrige National Quality Improvement Act (1987). The primary objective of the program is to help U. S. business improve their competitiveness in the global market by identifying role- model organizations, recognizing them and disseminating their practices throughout the United States.

Hypothesis 7: There is significant relationship between Balanced Scorecard and Change

\section{RESEARCH DESIGN}

\section{Need for study}

It has been observed after review of literature that balanced scorecard is used in order to rejuvenate organizations. This tool has also proved to be an effective tool resulting in better performing organizations. However, there has been no empirical study so far to show the relation between balanced scorecard and change, and their joint impact on organizational performance. Therefore, it was felt that there is need to explore the relation between balanced scorecard and change and how these affect performance of any organization.

\section{Objectives of study}

To study the concepts of balanced scorecard and change.

To assess the relationship between balance scorecard, change and organizational performance.

\section{Research Design}

Balanced scorecard and change are latent independent variables leading to organizational performance, which is dependent variable. Five constructs are identified for BSC namely: general, financial, customer, internal process, and learning and growth perspectives. For change five constructs namely; general, technological, social, leadership, and structural change are identified. In order to collect data on various dimensions of the study, a research instrument was designed based on extensive literature review. The instrument was based on five- point likert scale with choices 'strongly agree', 'agree', 'neither agree nor disagree', 'disagree' and 'strongly disagree'. The organizations chosen for the research fall under fortune 500 companies. Initially the questionnaire had 72 statements. The questionnaire was reviewed by experts for their feedback. After necessary modifications, senior managers were contacted for their responses since they are more aware of the application of balanced scorecard and changed occurring in the organization. The questionnaire was sent to 75 potential respondents, out of which only 50 responses were received. The reliablity and validity of the instrument was determined with the help of factor analysis and computing Cronbach alpha. The value of Chronbach alpha for the entire instrument as well as for each construct was more than 0.700 . Those variables with low factor loadings( less than 0.400) were deleted and the questionnaire was refined. As a result, 45 statements remained in the final questionnaire. After final data collection 105 responses turned out to be valid and considered for the analysis. 


\section{DATA ANALYSIS AND HYPOTHESES TESTS RESULTS}

TABLE 1: INDEPENDENT SAMPLE T- TEST

\begin{tabular}{|c|c|c|c|c|c|c|c|}
\hline \multicolumn{2}{|l|}{ Nature of industry } & $\mathbf{N}$ & Mean & $\begin{array}{c}\text { Std. } \\
\text { Deviation }\end{array}$ & $\begin{array}{c}\text { Std. } \\
\text { Error } \\
\text { Mean }\end{array}$ & $\mathbf{t}$ & $\begin{array}{c}\text { Sig. } \\
\text { (2-tailed) }\end{array}$ \\
\hline \multirow[t]{2}{*}{ General Perspective (BSC) } & 1 & 21 & 4.1429 & .76064 & .16599 & 1.023 & .309 \\
\hline & 2 & 84 & 4.2976 & .58143 & .06344 & & \\
\hline \multirow[t]{2}{*}{ Financial Perspective } & 1 & 21 & 4.0238 & .67964 & .14831 & .628 & .531 \\
\hline & 2 & 84 & 4.1865 & 1.13465 & .12380 & & \\
\hline \multirow[t]{2}{*}{ Customer Perspective } & 1 & 21 & 4.0357 & .69050 & .15068 & .379 & .706 \\
\hline & 2 & 84 & 4.0893 & .54970 & .05998 & & \\
\hline \multirow[t]{2}{*}{ Internal Business Process } & 1 & 21 & 3.9116 & .63964 & .13958 & .517 & .606 \\
\hline & 2 & 84 & 3.9830 & .54698 & .05968 & & \\
\hline \multirow[t]{2}{*}{ Learning and growth } & 1 & 21 & 3.7460 & .76307 & .16652 & .199 & .843 \\
\hline & 2 & 84 & 3.7817 & .73084 & .07974 & & \\
\hline \multirow[t]{2}{*}{ Balanced Scorecard } & 1 & 21 & 3.9720 & .55140 & .55140 & .736 & .463 \\
\hline & 2 & 84 & 4.0676 & .52760 & .52760 & & \\
\hline \multirow[t]{2}{*}{ General perspective(Change) } & & 21 & 4.0000 & .85147 & .18581 & .498 & .619 \\
\hline & 2 & 84 & 3.9048 & .76629 & .08361 & & \\
\hline \multirow[t]{2}{*}{ Technological Change } & 1 & 21 & 3.5238 & .82502 & .18003 & 2.241 & .027 \\
\hline & 2 & 84 & 3.8899 & .62618 & .06832 & & \\
\hline \multirow[t]{2}{*}{ Social Change } & 1 & 21 & 3.5952 & .69636 & .15196 & .228 & .820 \\
\hline & 2 & 84 & 3.6349 & .71627 & .07815 & & \\
\hline \multirow[t]{2}{*}{ Leadership Change } & 1 & 21 & 3.7619 & .94365 & .20592 & .431 & .667 \\
\hline & 2 & 84 & 3.6667 & .89676 & .09784 & & \\
\hline \multirow[t]{2}{*}{ Structural Change } & 1 & 21 & 3.9762 & .78224 & .17070 & .976 & .332 \\
\hline & 2 & 84 & 3.7619 & .92644 & .10108 & & \\
\hline \multirow[t]{2}{*}{ Change } & 1 & 21 & 3.7714 & .67535 & .14737 & .001 & .999 \\
\hline & 2 & 84 & 3.7716 & .67601 & .07376 & & \\
\hline \multirow[t]{2}{*}{ Performance } & 1 & 21 & 4.19 & .814 & .178 & .952 & .343 \\
\hline & 2 & 84 & 4.00 & .821 & .090 & & \\
\hline
\end{tabular}

Table 1 presents the $\mathrm{t}$ - value and significance difference on mean scores of balanced scorecard and change vis-à-vis manufacturing and service industry. There is no significant difference on mean scores of balanced scorecard with regard to service or manufacturing industry. Significant difference $(\mathrm{p}=.027)$ is found on the mean score of technological change vis-à-vis nature of industry. The mean value of technological change with respect to manufacturing and service sector comes out to be 3.5238 and 3.8899 respectively. There is no significant difference on mean scores of change with respect to nature of industry.

The above analysis shows that hypothesis 1 , stating that there is significant difference on mean scores of Balanced Scorecard vis-à-vis manufacturing and service industry, is rejected. Also hypothesis 2, stating that there is significant difference on mean scores of Change vis-à-vis manufacturing and service industry is rejected. 
TABLE 2: INDEPENDENT SAMPLE T- TEST

\begin{tabular}{|c|c|c|c|c|c|c|c|}
\hline \multicolumn{2}{|l|}{ Nature of Sector } & \multirow{3}{*}{$\begin{array}{l}\mathbf{N} \\
29 \\
76\end{array}$} & \multirow{3}{*}{$\begin{array}{c}\text { Mean } \\
4.2759 \\
4.2632\end{array}$} & \multirow{3}{*}{$\begin{array}{c}\begin{array}{c}\text { Std. } \\
\text { Deviation }\end{array} \\
.76064 \\
.58143\end{array}$} & \multirow{3}{*}{$\begin{array}{c}\begin{array}{c}\text { Std. Error } \\
\text { Mean }\end{array} \\
.51036 \\
.66067\end{array}$} & \multirow{3}{*}{$\begin{array}{r}\mathbf{t} \\
.093\end{array}$} & \multirow{3}{*}{$\frac{\begin{array}{c}\text { Sig. } \\
\text { (2-tailed) }\end{array}}{.926}$} \\
\hline General Perspective (BSC) & 1 & & & & & & \\
\hline & 2 & & & & & & \\
\hline \multirow[t]{2}{*}{ Financial Perspective } & 1 & 29 & 4.4885 & .67964 & 1.75760 & \multirow[t]{2}{*}{2.030} & \multirow[t]{2}{*}{.045} \\
\hline & 2 & 76 & 4.0263 & 1.13465 & .58376 & & \\
\hline \multirow[t]{2}{*}{ Customer Perspective } & 1 & 29 & 4.1638 & .69050 & .60973 & \multirow[t]{2}{*}{.934} & \multirow[t]{2}{*}{.353} \\
\hline & 2 & 76 & 4.0461 & .54970 & .56526 & & \\
\hline \multirow{2}{*}{$\begin{array}{l}\text { Internal Business } \\
\text { Process perspective }\end{array}$} & 1 & 29 & 4.0345 & .63964 & .57481 & \multirow[t]{2}{*}{.736} & \multirow[t]{2}{*}{.463} \\
\hline & 2 & 76 & 3.9436 & .54698 & .56186 & & \\
\hline \multirow{2}{*}{$\begin{array}{l}\text { Learning and } \\
\text { growth perspective }\end{array}$} & 1 & 29 & 3.5632 & .76307 & .88238 & \multirow[t]{2}{*}{1.844} & \multirow[t]{2}{*}{.068} \\
\hline & 2 & 76 & 3.8553 & .73084 & .65735 & & \\
\hline \multirow[t]{2}{*}{ Balanced Scorecard } & 1 & 29 & 4.1052 & .66137 & .12281 & \multirow[t]{2}{*}{.674} & \multirow[t]{2}{*}{.502} \\
\hline & 2 & 76 & 4.0269 & .47557 & .05455 & & \\
\hline \multirow[t]{2}{*}{ General perspective (Change) } & 1 & 29 & 4.0172 & .85147 & .61937 & \multirow[t]{2}{*}{.756} & \multirow[t]{2}{*}{.451} \\
\hline & 2 & 76 & 3.8882 & .76629 & .83506 & & \\
\hline \multirow[t]{2}{*}{ Technological Change } & 1 & 29 & 3.7241 & .82502 & .84342 & \multirow[t]{2}{*}{.857} & \multirow[t]{2}{*}{.393} \\
\hline & 2 & 76 & 3.8520 & .62618 & .61261 & & \\
\hline \multirow[t]{2}{*}{ Social Change } & $\mathbf{1}$ & 29 & 3.7644 & .69636 & .71063 & \multirow[t]{2}{*}{1.229} & \multirow[t]{2}{*}{.222} \\
\hline & 2 & 76 & 3.5746 & .71627 & .70627 & & \\
\hline \multirow[t]{2}{*}{ Leadership Change } & 1 & 29 & 3.9172 & .94365 & .86605 & 1.637 & .105 \\
\hline & 2 & 76 & 3.5974 & .89676 & .90598 & & \\
\hline Structural Change & 1 & 29 & 3.8621 & .78224 & .86496 & .401 & .689 \\
\hline & 2 & 76 & 3.7829 & .92644 & .91773 & & \\
\hline Change & 1 & 29 & 3.8570 & .64765 & .12027 & .803 & .424 \\
\hline & 2 & 76 & 3.7390 & .68328 & .07838 & & \\
\hline Performance & 1 & 29 & 4.10 & .814 & .900 & .503 & .616 \\
\hline & 2 & 76 & 4.01 & .821 & .792 & & \\
\hline
\end{tabular}

Table 2 presents the t- value and significance difference on mean scores of balanced scorecard and change vis-à-vis public and private sector. There is a significant difference on mean scores of financial perspective $(\mathrm{p}=.045)$ with respect to public and private sector. The mean scores of financial perspective come out to be 4.4885 and 4.0263 vis-à-vis public and private sector respectively. No significant difference is found on the mean scores of other dimensions of balanced scorecard with regard to public and private sector. The analysis also shows there is no significant difference on mean scores of various perspectives of change management vis-à-vis public and private sector.

The t- tests results illustrates there is no significant difference on mean scores of Balanced Scorecard vis-à-vis private and public sector. Thus, hypothesis 3 is rejected. No significant difference on mean scores of Change vis-à-vis private and public sector is found, therefore hypothesis 4 is also rejected. This implies that balanced scorecard as well as change practices are handled similarly in public and private sector organizations. 


\section{TABLE 3: CORRELATIONS AMONG BSC, CHANGE AND PERFORMANCE}

\begin{tabular}{|l|c|c|c|c|c|c|c|c|c|c|c|c|}
\hline & G & F & C & P & LG & BSC & GC & T & So & L & St & Change \\
\hline $\begin{array}{l}\text { General } \\
\text { Perspective (BSC) }\end{array}$ & 1 & & & & & & & & & & & \\
\hline Financial Perspective & $.348^{* *}$ & 1 & & & & & & & & & & \\
\hline Customer Perspective & $.370^{* *}$ & $.348^{* *}$ & 1 & & & & & & & & & \\
\hline $\begin{array}{l}\text { Internal Process } \\
\text { Perspective }\end{array}$ & $.515^{* *}$ & $.406^{* *}$ & $.526^{* *}$ & 1 & & & & & & & & \\
\hline $\begin{array}{l}\text { Learning and Growth } \\
\text { Perspective }\end{array}$ & $.457^{* *}$ & $.383^{* *}$ & $.539^{* *}$ & $.668^{* *}$ & 1 & & & & & & & \\
\hline Balanced Scorecard & $.689^{* *}$ & $.748^{* *}$ & $.704^{* *}$ & $.794^{* *}$ & $.795^{* *}$ & 1 & & & & & & \\
\hline $\begin{array}{l}\text { General } \\
\text { Perspective (Change) }\end{array}$ & $.380^{* *}$ & $.346^{* *}$ & $.552^{* *}$ & $.620^{* *}$ & $.563^{* *}$ & $.634^{* *}$ & 1 & & & & & \\
\hline Technological Change & $.409^{* *}$ & $.397^{* *}$ & $.548^{* *}$ & $.554^{* *}$ & $.560^{* *}$ & $.645^{* *}$ & $.585^{* *}$ & 1 & & & & \\
\hline Social Change & $.374^{* *}$ & $.428^{* *}$ & $.541^{* *}$ & $.719^{* *}$ & $.622^{* *}$ & $.700^{* *}$ & $.689^{* *}$ & $.618^{* *}$ & 1 & & & \\
\hline Leadership Change & $.357^{* *}$ & $.407^{* *}$ & $.614^{* *}$ & $.629^{* *}$ & $.656^{* *}$ & $.694^{* *}$ & $.643^{* *}$ & $.620^{* *}$ & $.837^{* *}$ & 1 & & \\
\hline Structural Change & $.223^{* *}$ & $.253^{* *}$ & $.467^{* *}$ & $.483^{* *}$ & $.516^{* *}$ & $.500^{* *}$ & $.417^{* *}$ & $.530^{* *}$ & $.688^{* *}$ & $.781^{* *}$ & 1 & \\
\hline Change & $.406^{* *}$ & $.428^{* *}$ & $.643^{* *}$ & $.706^{* *}$ & $.690^{* *}$ & $.746^{* *}$ & $.746^{* *}$ & $.777^{* *}$ & $.905^{* *}$ & $.929^{* *}$ & $.827^{* *}$ & 1 \\
\hline Performance & $.424^{* *}$ & $.392^{* *}$ & $.552^{* *}$ & $.564^{* *}$ & $.614^{* *}$ & $.665^{* *}$ & $.380^{* *}$ & $.494^{* *}$ & $.543^{* *}$ & $.653^{* *}$ & $.519^{* *}$ & $.617^{* *}$ \\
\hline
\end{tabular}

**. Correlation is significant at the 0.01 level (2-tailed).

*. Correlation is significant at the 0.05 level (2-tailed).

The results of correlation exhibit significant relationship between balanced scorecard and organizational performance. Thus, hypothesis 5 is accepted. Analysis also shows significant relationship between change and organizational performance as a result hypothesis 6 is accepted. The value of $r$ shows there is significant relationship between balanced scorecard and change. Hypothesis 7, stating there is significant relationship between balanced scorecard and change is accepted. This implies that balanced scorecard perspectives and change positively impact the performance of the organizations. If balanced scorecard is used properly, change will be effective leading to effective and high performance.

\section{FIGURE 1: MODEL PRESENTING VALUE OF CORRELATION}

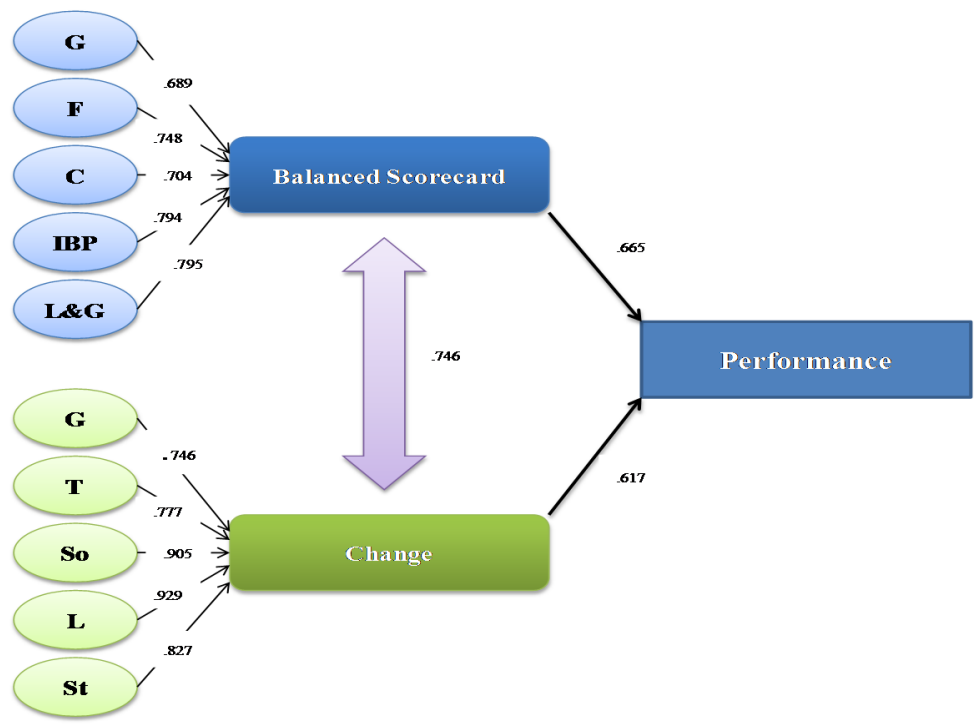




\section{CONCLUSION}

By now, the Balanced Scorecard's universal appeal as a management approach is well established. BSC provides a visual framework that integrates the organization's strategic objectives across these four perspectives. Change is more likely to happen when a clear reason for it exists. Any change effort offers both short-and long-term impact on organizational performance. The results of the study show that Indian organizations have incorporated the dimensions of BSC as a performance measurement tools and use it to create change and improve performance. There is not much difference in the use of BSC between public and private sector as well as service and manufacturing organizations.

Results also suggest that private and public sector organizations differ on the dimension of technological change while service and manufacturing organizations differ on financial perspective. BSC , change and performance are highly correlated to each other thus substantiating the argument that performance is affected by BSC and change. 


\section{REFERENCES}

Abernethy, M. A. and Lillis, A. (1995) 'The impact of manufacturing flexibility on management control system design', Accounting, Organizations and Society 20: 241- 258.

Borman, G.D., Rachuba, L., Datnow, A., Alberg, M., Mac Iver, M. and Stringfield, S. (2000)

'FourModels of School Improvement: Successes and Challenges in Reforming Low-performing, High -poverty Title I Schools', Center for Research on the Education of Students Placed At Risk (CRESPAR), Baltimore, MD (Report No. 48).

Bose, S. \& Thomas, K. (2007) 'Applying the balanced scorecard for better performance of intellectual capital', Journal of Intellectual Capital 8(4): 653-654.

Brady, R.C. (2003) 'Can Failing Schools be Fixed?’ Thomas B. Fordham Foundation, Washington, DC.

Buhovac, A. R. and Slapničar, S. (2007) 'The Role of Balanced, Strategic, Cascaded and Aligned Performance Measurement in Enhancing firm performance', Economic and Business Review for Central and South- Eastern Europe 9(1): 47- 74.

Chenhall, R. H. (1997) 'Reliance on Manufacturing Performance Measures, Total Quality Management and Organizational Performance', Management Accounting Research 8: 187- 206.

Cibulka, J.G. (2003) 'Educational bankruptcy, takeovers, and reconstitution of failing schools', in Boyd, W.L. and Miretzky, D. (Eds), American Educational Governance on Trial: Changeand Challenges, National Society for the Study of Education, Chicago, IL, 249-70.

Cyert, R. M., and March, J. (1963) ‘A Behavioral Theory of the Firm’ NJ: Prentice- Hall.

Davis, S. and Albright, T. (2004), An investigation of the effect of balanced scorecard implementation on financial performance, Management Accounting Research, 15(2), pp. 135- 153.

Dent, E. B., \& Goldberg, S. G. (1999), Challenging "resistance to change', Journal of Applied Behavioral Sciences, 35(25), pp. 25-41.

Duke, D.L. (2007), Turning schools around, Education Week, 26(4), pp.35-37.

Harber, B. W. (1998), The balanced scorecard solution at Peel Memorial Hospital, Hospital Quaterly, pp.52- 62.

Hedberg, B. (1981), How Organizations Learn and Unlearn in Nystrom, P. C. and Starbuck, W. eds. Handbook of organizational design, Oxford University Press, England.

George, J. M., \& Jones, G. R. (2001), Towards a process model of individual change in organizations, Human Relations, 54(4), pp.419-444.

Ittner, C. D. (2008), Does measuring intangibles for management purposes improve performance? A review of the evidence, Accounting and Business Research, 38(3), pp.261-272.

Ittner, C. D. and Larcker, D. F. (1995), Total Quality Management and the Choice of Information and Reward System, Journal of Accounting Research, 33, pp.1- 34.

Ittner, C. D., Larcker, D. F. and Meyer, M. W. (2003), Subjectivity and the weighing of performance measures: Evidence from a Balanced Scorecard, The Accounting Review, 78(3), pp.725- 758.

Kaplan, R.S. and Norton, D.P. (1992), The balanced scorecard - measures that drive Performance, Harvard Business Review, 70(1), pp.172- 180.

Kaplan, R. S. and Norton, D. P. (1993), Putting the Balanced Scorecard to Work, Harvard Business Review, September- October, pp.134- 147.

Kaplan, R. S. and Norton, D. P. (1996), The Balanced Scorecard: Translating strategy into action, Harvard Business School Press, Boston.

Kaplan, R. \& Norton, D. (1996b), Strategic learning \& the balanced scorecard, Strategy\& Leadership, 24(5), pp.18-25.

Kaplan, R.S. and Norton, D.P. (2000), Strategy Maps: Converting Intangible Assets into Tangible Outcomes, Harvard Business School Press, Boston, MA. 
Kaplan, R. S. and Norton, D. P. (2002), The balanced scorecard- measures that drive performance, Harvard Business Review, pp.71- 79.

Kaplan, R. S. and Norton, D. P. (2004), Strategy Maps: Converting Intangible Assets into Tangible Outcome, Harvard Business School Press, Boston.

Kaynak, H. (2003), The relationship between total quality management practices and their effects on firm performance, Journal of Operations Management, 21, pp.405- 435.

Kowal, J.M. and Hassel, E.A. (2005), Turnarounds with New Leaders and Staff, Learning Point Associates/North Central Regional Educational Laboratory (NCREL), Naperville, IL.

Lawrence, S. and Sharma, U. (2002), Commodification of education and academic labor- using balanced scorecard in a university setting, Critical Perspectives on Accounting, 13(5/6), pp.661- 677.

Levitt, B. and March, J. (1988), Organizational Learning, Annual Rev. Sociology, 14, pp.319-340.

Levy, N. (1998), Managing High Technology and Innovation, Prentice-Hall, Englewood Cliffs, New Jersey.

Lewin, K. (1951), Field theory in social science, Harper, New York.

Littler, K., Aisthrope, P., Hudson, R. and Keaysey, K. (2009), A new approach to linking strategy formulation and stratefy implementation: an example from the UK banking sector, International Journal of Information Management, 20(6), pp.411- 428.

MacStravic, S. (1999), A really balanced scorecard, Health Forum, May/ June, pp.64- 67.

March, J.G. and Simon, H. (1958), Organizations, John Wiley and Sons, New York.

Marrow, A. J. (1957), Making management human, McGraw-Hill, New York.

McColskey, W. and Monrad, D.M. (2004), Assisting low-performing schools in the Southeast, International Journal of Educational Police, Research and Practice, 4(4), pp.3-24.

McDevitt, R., Giapponi, C. and Solomon, N. (2008), Strategy revitalization in academe: a balanced scorecard approach, International Journal of Educational Management, 22(1), pp.32-47.

Mintrop, H. and MacLellan, A. (2002), School improvement plans in elementary and middle schools on probation, Elementary School Journal, 102(4), pp.275-300.

Mintrop, H. and Trujillo, T. (2005), Corrective action in low performing schools: lessons for NCLB implementation from first-generation accountability systems, Education Policy Analysis Archives, 13 (8), pp.1-30.

Morgan, G. (1989), Reading the Waves of Change, Jossey- Bass Publishers, San Francisco.

Narrett, A. (2008), Keeping Score, American Gas, pp.22- 25.

Neely, A., Adams, C., Kennerley, M. (2002), The Performance Prism: The Scorecard for Measuring and Managing Business Success, Financial Times Prentice Hall, London.

Niven, P. (2002), Balanced scorecard step-by-step: Maximizing performance and maintaining results, John Wiley \& Sons, Inc., New York.

Pierce, J. and Delbecq, A. (1977), Organizational Structure, Individual Attitudes and Innovation, Academy of Management Review, pp.27-37.

Perera, S., Harrison, G. and Pole, M. (1997), Customer- focused Manufacturing Strategy and the use of operations- based non- financial performance measures: A research note, Accounting Organizations and Society, 22, pp.557- 572.

Phenix, D., Siegel, D., Zaltsman, A. and Fruchter, N. (2005), A forced march for failing schools:lessons from the New York City Chancellor's District, Educational Policy Analysis Archives, 13(40), pp.1-21.

Robbins, S. P. (2001), Organizational Behavior, Prentice Hall of India, New Delhi.

Said, A. A., HassabElnaby, H. R. and Wier, B. (2003), An empirical investigation of the performance consequences of non- financial measures, Journal of Management Accounting Research, 15, pp.193223. 
Stickland, F. (1998), The Dynamics of Change, Routledge, London.

Struckman, C. K., \& Yammario, F. J. (2003), Organizational change: A categorization scheme and response model with readiness factors, Research in organizational change and development, 14, pp.150 .

Thomas, R., Gable, M. and Dickinson, R. (1999), An application of balanced scorecard in retailing, The International Review of Retail, Distribution and Consumer Research, 9(1), pp.41- 67.

Van De Ven, A. H., \& Poole, M. S. (1995), Explaining development and change in organizations, Academy of Management Review, 20(3), pp.510-540.

Watchtel, T.R., Hartford, C. E. and Hughes, J. A. (1999), Building a balanced scorecard for a burns center, Burns, 25(5), 431- 437.

Wang, M.C. and Manning, J. (2000), Turning Around Low-performing Schools: The Case of the Washington, DC Schools, Office of Educational Research and Improvement, Washington, DC (Report 143). 